\title{
Identification and Environmental Issues of Polluted Sea Water
}

\author{
S. Abdul Gafoor, R. Nasar Ali, M. Shahul Hameed, S.Sabeena Begum, D. Zunaithur Rahman
}

\begin{abstract}
Marine pollution is a major problem nowadays in our country. Contamination is the entrance into the environment of toxic chemicals. Every material that has undesirable changes in its composition, position or quantity can be the pollutant in terms of the physical, chemical or biological properties of air, water, and soil. The pollution level is higher in the nearby seashore because the density of waves is lower in the nearby sea. $70 \%$ to $80 \%$ of oxygen for humans comes from the sea. Marine pollution generally affects ecosystem health, public health, quality of recreational water and economic viability in the following ways: Mechanical, Saphrogenic, Mutagenic, and Carcinogenic. Non-biodegradable plastic is a large portion and a major danger. Sea turtles err in their jellyfish plastic bags and die from internal blockages. 100,000 marine mammals are killed and two million birds die every year. The water is contaminated by pollution by the precipitation of the soil, by air-borne rain and by shipwrecks. Human activity releases 5-fold mercury and17-fold lead from natural sources. Tourism development results in water pollution not only in water-scarce areas with relatively abundant water resources. Because water is used extensively in the tourism industry, it is apparent that during tourism growth, tourism will have an important impact on the climate of the water, including water pollution and a lack of water, which are the key barriers to the creation of a sustainable tourism industry. Solid waste disposal in the sea (they didn't decompose they get dumped inside the sea). Due to ship accidents in the sea oil gets contaminant inside the sea, some special species are fully destroyed because of this problem. So we are collecting a water sample from East Coast Region in Ramanathapuram District, Tamilnadu, India. Detect the amount of pollution in the water sample through a test and compared it with permissible limits.
\end{abstract}

Keywords : Pollution, Seawater, Case study, Chemical Characteristics, Analysis

Revised Manuscript Received on April 25, 2020.

* Correspondence Author

S.Abdul Gafoor*, Assistant Professor, Department of Civil Engineering, Mohamed Sathak Engineering College, Kilakarai - 623 806, Tamil Nadu, India. College of Engineering and Technology, Samara University, Afar-7260, Ethiopia.

M.Shahul Hameed, Research Scholar, National Institute of Technical Teachers Training and Research, Chennai-600 113, Tamilnadu, India.

S.Sabeena Begum, Assistant Professor, Department of Physics, Mohamed Sathak Engineering College, Kilakarai - 623 806, Tamil Nadu, India.

D.Zunaithur Rahman, Assistant Professor, Department of Civil Engineering, Mohamed Sathak Engineering College, Kilakarai - 623 806, Tamil Nadu, India.

(c) The Authors. Published by Blue Eyes Intelligence Engineering and Sciences Publication (BEIESP). This is an open access article under the CC BY-NC-ND license (http://creativecommons.org/licenses/by-nc-nd/4.0/)
R.Nasar Ali, Assistant Professor, Department of Civil Engineering,

\section{INTRODUCTION}

The water component of Earth's seas, lakes, rivers and most of the waters of living organisms is the translucent and almost colorless chemical substance [1]. Water applies specifically to the liquid form and normal external temperature and pressure of such a substance; however, it also refers often to the solid-state (ice) or it's gas (steam or water vapor) [2,3]. 71 percent of the Earth's surface is covered by water. For all known life forms, it is vital. On Earth, the atmosphere and the oceans account for $96.5 \%$ of the planet's surface water [4].

Water quality analyses are an integral part of an environmental monitoring program for touristic beaches, and in general, present important information for the management of the coastal zone. Amongst the various human activities found in the coastal zone, beach tourism represents one of the most important uses, given its economic significance especially $[5,6,7]$. However, the conservation of a beach's environmental quality may present challenges, as land-based activities can affect coastal water quality. Consequently, effective management of touristic beaches and their related environmental services requires an up to date knowledge of coastal water quality [8]. A water quality monitoring program should include the analysis of various different parameters to report on a beach's recreational, aesthetic and ecosystem properties. A water body's adequacy for recreational use is commonly monitored with physical and chemical parameters [9].

According to the World Health Organisation (WHO), about $80 \%$ of all diseases in human beings are caused by water. The aesthetic quality of a water body could be defined as the water's clarity, which can be characterized by a number of parameters, such as hardness, turbidity or total suspended solids (TSS) [10].

Parameters indicative of water quality with respect to ecosystem conservation could include all of the aforementioned parameters. Indicators of eutrophication are furthermore pertinent for ecosystem conservation as nutrient-rich waters may shift the ecological balance of coral reef ecosystems in the favor of macroecological dominance while eutrophic waters are limited in dissolved oxygen which is critical for marine organisms [11]. Additionally, monitoring of the Physico-chemical parameters dissolved oxygen, temperature, salinity, and $\mathrm{pH}$ is important for ecosystem conservation as marine organisms are known to live within given ranges of these parameters, the divergence of which could lead to the hindrance of growth, 


\section{Identification and Environmental Issues of Polluted Sea Water}

mortality and an overall reduction in ecosystem [12].

\section{A. Importance of the study}

$80 \%$ of marine non-biological pollution is caused by land-based activities.

The most noticeable inputs through marine water drainage pipes [13]. The river flows into the sea of contaminants from the whole area of the catchment. Air discharges regional air supplies to the sea. Designated dumping ground at sea (drawn waste, oil ammunition, sludge, fly ash, oils) [14,15].

We need to understand water quality in order to protect our health, and also the health of ecosystems. As water moves from one river to another, all water contamination flows with it and is capable of reaching thousands of communities [16]. Some water pollution actually begins with air pollution in the oceans. Pollutants can be dirt. Pollution from nonpoint sources may cause river and ocean water to harm people and wildlife. This contamination is so extreme in certain places that after the rainstorms beaches are closed $[17,18]$.

\section{B. Objectives of the study}

- To prevent the pollution rate.

- To take initiative to conserve and restore the biodiversity in the project areas.

- To save the life of special species.

- To identify the affected places within the study area.

\section{STUDY AREA AND METHODOLOGY}

We choose the study at East Coast Region in Ramanathapuram Municipal in the southern part of Tamil Nadu, India.

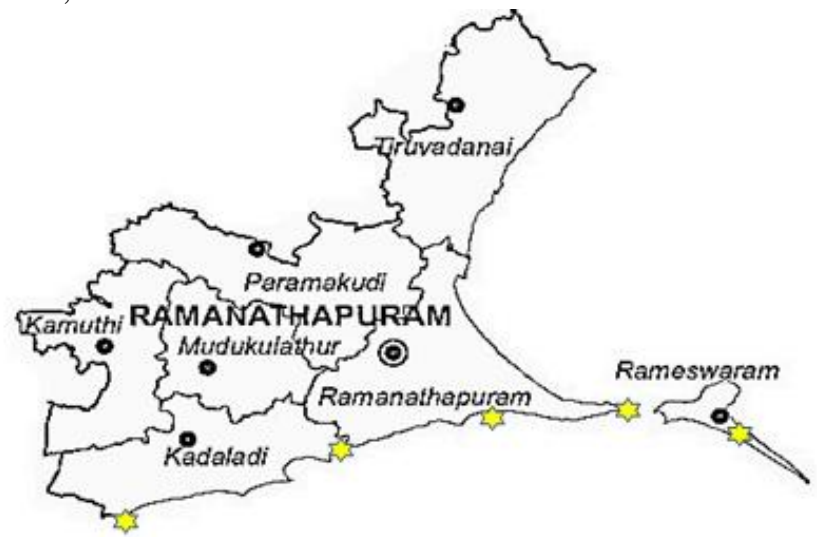

Fig 1. Study area and sample collection locations

The district of Ramanathapuram is an urban district in southern India in Tamil Nadu. The area of the district is 4123 $\mathrm{km} 2$ and was populated in the 2011 census by 1,353,445 people. It is 9016' N to 77026' E. The gulf of Mannar borders the south and the district of Thoothukudi to the west. This district comprises the Pamban Bridge, an eastern-west chain of elevated and medium coral islands extends between India and Sri Lanka, dividing Palk Straits from Mannar Gulf. Marine formation consists of varying proportions of coastal flat deposits of sand and clay. Marine hardpan calcareous occurs as small terraces and platforms, with admixture of quartz, limonite and garnet concentration.

Marine Biosphere Reserve not only in India but also in Southeast Asia. One of the biologically richest coastal areas on India's coastline is the Mannar Gulf and its 3600 flora and fauna species. It is also abundant in seabeds, seaweeds, pearl banks of coral reef, fines and shellfish. The dugong, which is frequently called the pig, is an important sanctuary for a marine animal critically endangered. In the Gulf of Mannar, there are 137 coral species. Sponges, though they look like plants or animals at a casual glance, live individually or in colonies of many people. The Gulf of Mannar contains 275 species below 8 orders. In the sponges, many animals have these sponges, ranging from tiny crabs and brittle stars to bivalve mollusks.

\section{A. Methodology of the study}

- Study Area

- Collection of Water Sample

- Characterization of water sample

- Result and Discussion

- Analysis of result compared to Limits

- Conclusion

\section{RESULTS AND DISCUSSION}

\section{A. Results}

Table 1. pH Level in Study Area

\begin{tabular}{|c|c|c|c|}
\hline Sample Area & $\mathrm{pH}$ Level & Remarks & Permissible Limit \\
\hline Sethukarai & 7.5 & Fit & \multirow{3}{*}{ Fit $(7.5-8.4)$} \\
Rameswaram & 8.0 & Fit & Unfit $(<7.5$ and \\
Kilakarai & 8.0 & Fit & F.5) \\
\hline Naripaiyur & 8.0 & Fit & \\
\hline Naalupannai & 7.5 & Fit & \\
\hline
\end{tabular}

Table 2. Alkalinity Level in Study Area

\begin{tabular}{|c|c|c|c|}
\hline Sample Area & $\begin{array}{c}\text { Alkalinity Level } \\
\text { (mg/l) }\end{array}$ & Remarks & $\begin{array}{l}\text { Permissible } \\
\text { Limit (mg/l) }\end{array}$ \\
\hline Sethukarai & 400 & Unfit & \multirow{5}{*}{$\begin{array}{c}\text { Fit }(<100) \\
\text { Moderate } \\
(100-125) \\
\text { Unfit }(>125)\end{array}$} \\
\hline Rameswaram & 250 & Unfit & \\
\hline Kilakarai & 250 & Unfit & \\
\hline Naripaiyur & 150 & Unfit & \\
\hline Naalupannai & 250 & Unfit & \\
\hline
\end{tabular}

Table 3. Hardness Level in Study Area

\begin{tabular}{|c|c|c|c|}
\hline Sample Area & $\begin{array}{c}\text { Hardness } \\
\text { Level (mg/l) }\end{array}$ & Remarks & $\begin{array}{l}\text { Permissible Limit } \\
\text { (mg/l) }\end{array}$ \\
\hline Sethukarai & 15,000 & Moderate & \multirow{5}{*}{$\begin{array}{c}\text { Fit }(<10,000) \\
\text { Moderate } \\
(10,000-35,000) \\
\text { Unfit }(>35,000)\end{array}$} \\
\hline Rameswaram & 18,000 & Moderate & \\
\hline Kilakarai & 20,000 & Moderate & \\
\hline Naripaiyur & 13,000 & Moderate & \\
\hline Naalupannai & 17,000 & Moderate & \\
\hline
\end{tabular}

Table 4. Chloride Level in Study Area

\begin{tabular}{|c|c|c|c|}
\hline Sample Area & $\begin{array}{c}\text { Chloride Level } \\
(\mathrm{mg} / \mathrm{l})\end{array}$ & Remarks & $\begin{array}{l}\text { Permissible } \\
\text { Limit (mg/l) }\end{array}$ \\
\hline Sethukarai & 16,000 & Unfit & \multirow{5}{*}{$\begin{array}{c}\text { Fit }(<500) \\
\text { Moderate } \\
(500-5000) \\
\text { Unfit }(>5000)\end{array}$} \\
\hline Rameswaram & 17,000 & Unfit & \\
\hline Kilakarai & 18,000 & Unfit & \\
\hline Naripaiyur & 15,000 & Unfit & \\
\hline Naalupannai & 15,000 & Unfit & \\
\hline
\end{tabular}

Table 5. Fluoride Level in Study Area

\begin{tabular}{|c|c|c|c|}
\hline Sample Area & $\begin{array}{c}\text { Fluoride Level } \\
(\mathrm{mg} / \mathrm{l})\end{array}$ & Remarks & $\begin{array}{l}\text { Permissible } \\
\text { Limit (mg/l) }\end{array}$ \\
\hline Sethukarai & 3.0 & Unfit & \multirow{5}{*}{$\begin{array}{c}\text { Fit }(<0.86) \\
\text { Moderate } \\
(0.86-1.4) \\
\text { Unfit }(>1.4)\end{array}$} \\
\hline Rameswaram & 2.0 & Unfit & \\
\hline Kilakarai & 1.5 & Unfit & \\
\hline Naripaiyur & 1.0 & Moderate & \\
\hline Naalupannai & 0.5 & Fit & \\
\hline
\end{tabular}

Published By:

Blue Eyes Intelligence Engineering

\& Sciences Publication

DOI: 10.35940/ijeat.D8353.049420

Journal Website: www.ijeat.org 
Table 6. Iron Level in Study Area

\begin{tabular}{|c|c|c|c|}
\hline Sample Area & $\begin{array}{l}\text { Iron Level } \\
(\mathrm{mg} / \mathrm{l})\end{array}$ & Remarks & $\begin{array}{l}\text { Permissible Limit } \\
(\mathrm{mg} / \mathrm{l})\end{array}$ \\
\hline Sethukarai & 0 & Fit & \multirow{5}{*}{$\begin{array}{c}\text { Fit }(<1,000) \\
\text { Moderate } \\
(1,000-3,000) \\
\text { Unfit }(>3,000)\end{array}$} \\
\hline Rameswaram & 0 & Fit & \\
\hline Kilakarai & 0 & Fit & \\
\hline Naripaiyur & 0 & Fit & \\
\hline Naalupannai & 0 & Fit & \\
\hline
\end{tabular}

\begin{tabular}{|c|c|c|c|}
\hline Sample Area & $\begin{array}{c}\text { Phosphate } \\
\text { Level (mg/l) }\end{array}$ & Remarks & $\begin{array}{l}\text { Permissible } \\
\text { Limit (mg/l) }\end{array}$ \\
\hline Sethukarai & 1.0 & Unfit & \multirow{5}{*}{$\begin{array}{c}\text { Fit }(0) \\
\text { Moderate } \\
(0-0.03) \\
\text { Unfit }(>0.03)\end{array}$} \\
\hline Rameswaram & 0.5 & Unfit & \\
\hline Kilakarai & 0.5 & Unfit & \\
\hline Naripaiyur & 0.5 & Unfit & \\
\hline Naalupannai & 0.5 & Unfit & \\
\hline
\end{tabular}

Table 7. Ammonia Level in Study Area

\begin{tabular}{|c|c|c|c|}
\hline Sample Area & $\begin{array}{c}\text { Ammonia } \\
\text { Level (mg/l) }\end{array}$ & Remarks & $\begin{array}{l}\text { Permissible } \\
\text { Limit (mg/l) }\end{array}$ \\
\hline Sethukarai & 1.0 & Moderate & \multirow{5}{*}{$\begin{array}{c}\text { Fit }(<0.02) \\
\text { Moderate } \\
(0.02-1.4) \\
\text { Unfit }(>1.4)\end{array}$} \\
\hline Rameswaram & 1.0 & Moderate & \\
\hline Kilakarai & 1.0 & Moderate & \\
\hline Naripaiyur & 1.0 & Moderate & \\
\hline Naalupannai & 1.0 & Moderate & \\
\hline
\end{tabular}

Table 11. Residual Chloride Level in Study Area

\begin{tabular}{|c|c|c|c|}
\hline Sample Area & $\begin{array}{c}\text { Residual } \\
\text { Chloride } \\
\text { Level (mg/l) }\end{array}$ & Remarks & $\begin{array}{l}\text { Permissible Limit } \\
\text { (mg/l) }\end{array}$ \\
\hline Sethukarai & 3.0 & Unfit & \multirow{5}{*}{$\begin{array}{c}\text { Fit }(0) \\
\text { Moderate }(0-0.5) \\
\text { Unfit }(>0.5)\end{array}$} \\
\hline Rameswaram & 2.0 & Unfit & \\
\hline Kilakarai & 3.0 & Unfit & \\
\hline Naripaiyur & 2.0 & Unfit & \\
\hline Naalupannai & 3.0 & Unfit & \\
\hline
\end{tabular}

Table 8. Nitrite Level in Study Area

\begin{tabular}{|c|c|c|c|}
\hline Sample Area & $\begin{array}{c}\text { Nitrite Level } \\
(\mathrm{mg} / \mathrm{l})\end{array}$ & Remarks & $\begin{array}{c}\text { Permissible } \\
\text { Limit }(\mathrm{mg} / \mathrm{l})\end{array}$ \\
\hline Sethukarai & 45 & Unfit & \multirow{2}{*}{$\begin{array}{c}\text { Fit }(<0.1) \\
\text { Moderate } \\
(0.1-20)\end{array}$} \\
Rameswaram & 20 & Moderate & Unfit \\
Unfit $(>20)$
\end{tabular}

Table 9. Nitrate Level in Study Area

\begin{tabular}{|c|c|c|c|}
\hline Sample Area & $\begin{array}{c}\text { Nitrate } \\
\text { Level (mg/l) }\end{array}$ & Remarks & $\begin{array}{l}\text { Permissible Limit } \\
(\mathrm{mg} / \mathrm{l})\end{array}$ \\
\hline Sethukarai & 45 & Unfit & \multirow{5}{*}{$\begin{array}{c}\text { Fit }(<0.1) \\
\text { Moderate }(0.1-20) \\
\text { Unfit }(>20)\end{array}$} \\
\hline Rameswaram & 20 & Moderate & \\
\hline Kilakarai & 45 & Unfit & \\
\hline Naripaiyur & 20 & Moderate & \\
\hline Naalupannai & 20 & Moderate & \\
\hline
\end{tabular}

Table 12. Total Dissolved Solids Level in Study Area

\begin{tabular}{|c|c|c|c|}
\hline Sample Area & $\begin{array}{c}\text { Total } \\
\text { Dissolved } \\
\text { Solids Level } \\
(\mathrm{mg} / \mathrm{l})\end{array}$ & Remarks & $\begin{array}{c}\text { Permissible Limit } \\
(\mathrm{mg} / \mathrm{l})\end{array}$ \\
\hline Sethukarai & 3,750 & Unfit & \multirow{2}{*}{$\begin{array}{c}\text { Fit }(<500) \\
\text { Moderate } \\
(500-2,000)\end{array}$} \\
\hline Rameswaram & 4,250 & Unfit & Unfit $(>2,000)$ \\
\hline Kilakarai & 4,500 & Unfit & Unfit \\
\hline Naripaiyur & 3,250 & Unfit & \\
\hline Naalupannai & 3,750 & &
\end{tabular}

\section{A. Analysis of Results}

*S.min and S.max - Minimum and maximum permissible limits, SK - Sethukarai, RM - Rameswaram, KL - Kilakarai, NP - $\quad$ Naripaiyur, PN $\quad-\quad$ Naalupannai

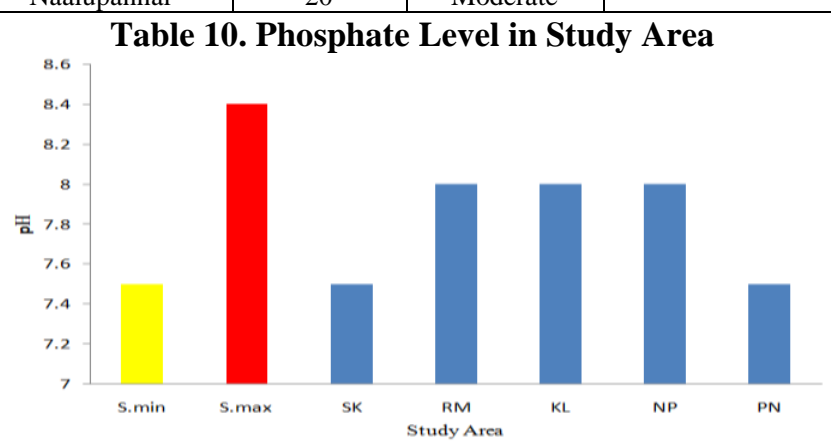

Fig 2. pH Level in Study Area

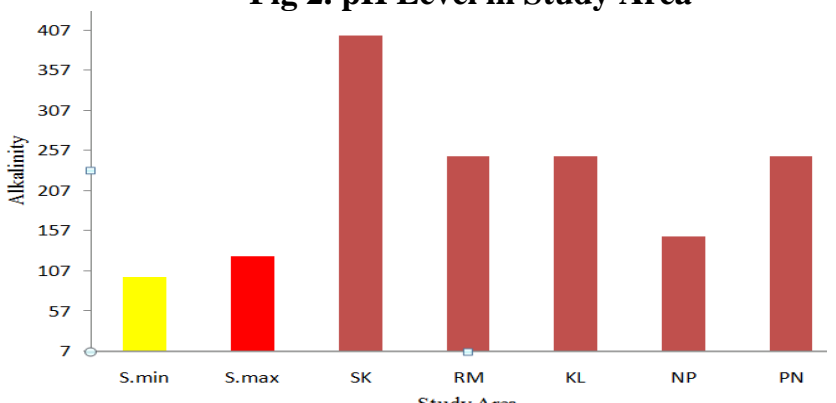

Fig 3. Alkalinity Level (mg/l) in Study Area

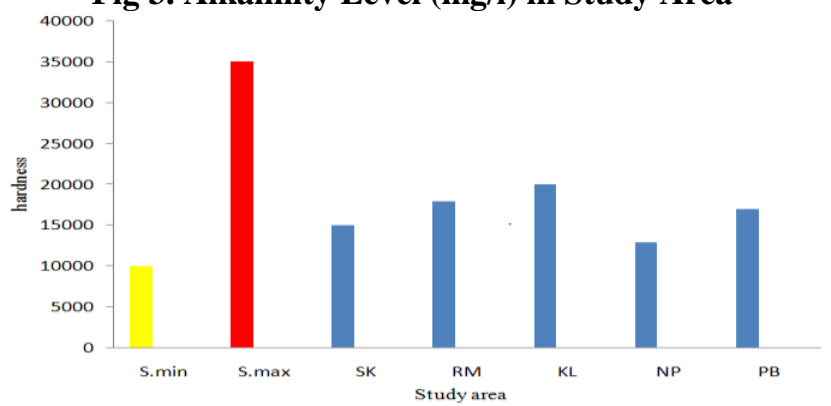

Fig 4. Hardness Level (mg/l) in Study Area

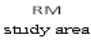

Fig 7. Iron Level (mg/l) in Study Area

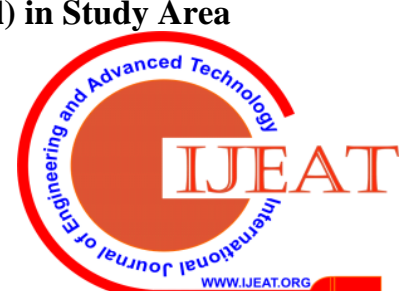




\section{Identification and Environmental Issues of Polluted Sea Water}

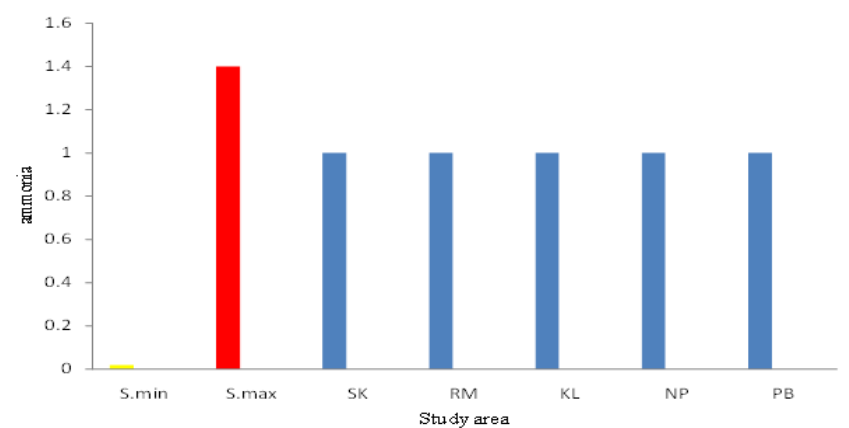

Fig 8. Ammonia Level (mg/l) in Study Area

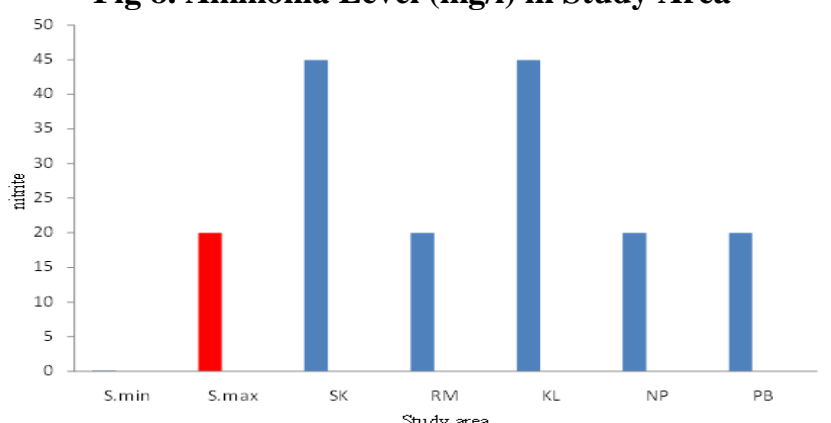

Fig 9. Nitrite Level (mg/l) in Study Area

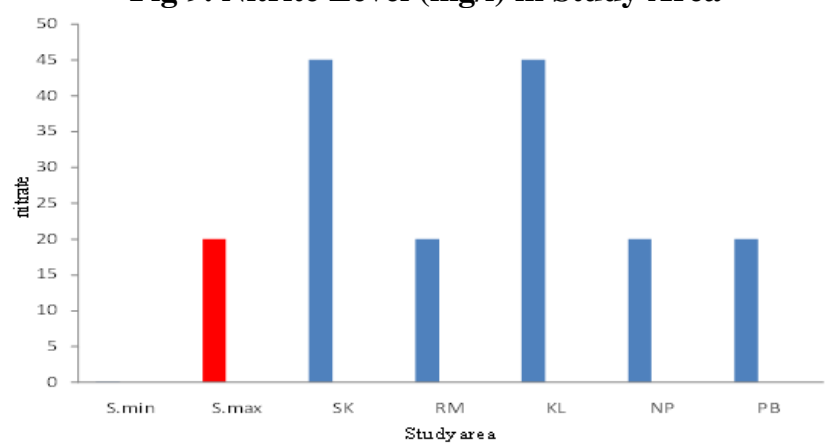

Fig 10. Nitrate Level (mg/l) in Study Area

\section{B. Discussion}

$\mathrm{pH} \quad \rightarrow$ As per standards desirable limit for $\mathrm{pH}$ is 7.5 to 8.4 in the east coast region. In all the study areas $\mathrm{pH}$ values vary from 7.5 to 8 , So the water samples are within permissible limits. No contamination affects $\mathrm{pH}$

Alkalinity $\rightarrow$ As per standards, alkalinity value ranges from 100 to $125 \mathrm{mg} / \mathrm{l}$ in the east coast region. In all the study areas alkalinity value varies from 150 to $400 \mathrm{mg} / \mathrm{l}$, which is unfit level. Contamination affect alkalinity, it causes gastrointestinal issues and skin irritations for human health.

Hardness $\rightarrow$ As per standards hardness value ranges from 10000 to $35000 \mathrm{mg} / \mathrm{l}$ in the east coast region. In all the study areas hardness value varies from 13000 to $20000 \mathrm{mg} / \mathrm{l}$, so the water samples are within permissible limits. No contamination affects hardness.

Chloride $\rightarrow$ As per standards chloride value ranges from 500 to $5000 \mathrm{mg} / \mathrm{l}$ in the east coast region. In all the study areas chloride value varies from 15000 to $18000 \mathrm{mg} / \mathrm{l}$, which is unfit level. Contamination affects chlorides, it causes respiratory distress, convulsions, and death.

Fluoride $\rightarrow$ As per standards fluoride value ranges from

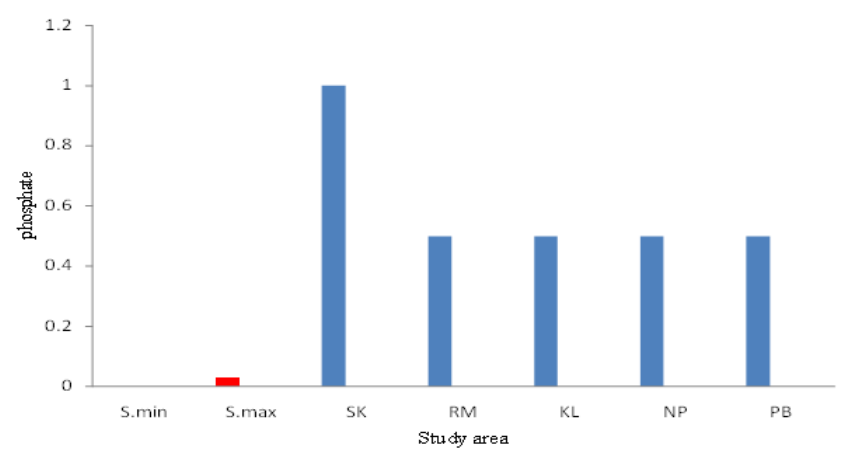

Fig 11. Phosphate Level (mg/l) in Study Area

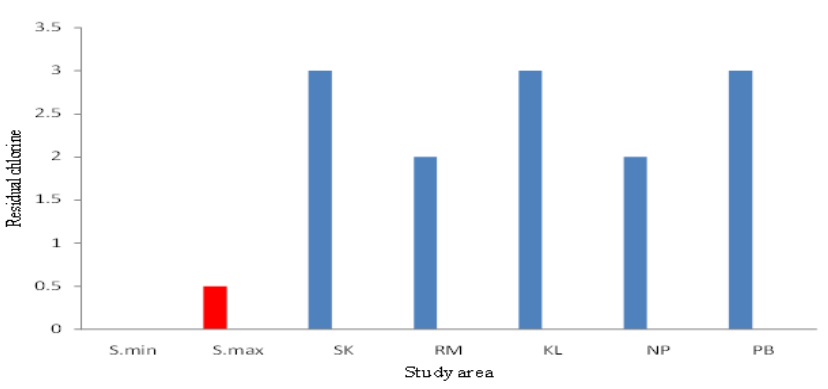

Fig 12. Residual Chloride Level (mg/l) in Study Area

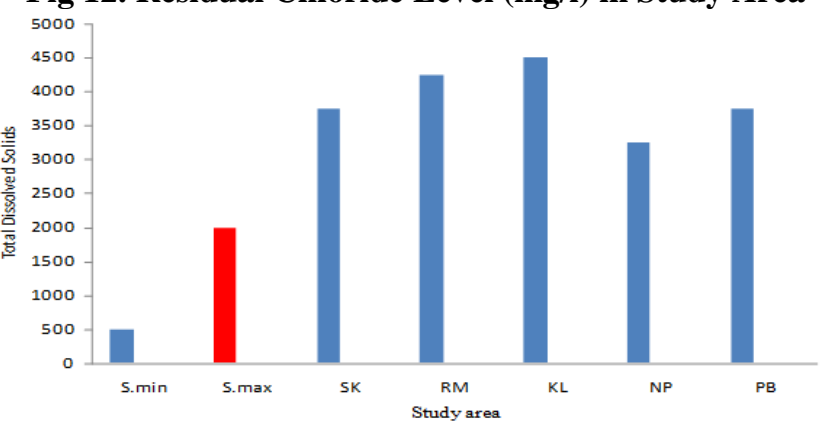

Fig 13. Total Dissolved Solids Level (mg/l) in Study Area 0.86 to $1.4 \mathrm{mg} / \mathrm{l}$ in the east coast region. In all the study areas fluoride value varies from 0.5 to $3 \mathrm{mg} / \mathrm{l}$ which is unfit level. Contamination affect chlorides, it causes harm to kidney, bones, reproductive organs, nerve and muscles for human health.

Iron $\rightarrow$ As per standards desirable limit for iron, value ranges from 1000 to $3000 \mathrm{mg} / \mathrm{l}$ in the east coast region. In all the study areas iron values are $0 \mathrm{mg} / \mathrm{l}$, so the water samples are within permissible limits. No contamination affects iron.

Ammonia $\rightarrow$ As per standards ammonia value ranges from 0.02 to $1.4 \mathrm{mg} / \mathrm{l}$ in the east coast region. In all the study areas ammonia value varies from $1 \mathrm{mg} / \mathrm{l}$ which is unfit level. Contamination affects ammonia, it causes toxic to aquatic organisms, toxic buildup in internal tissues and blood leads to potentially deadly. 


\section{Identification and Environmental Issues of Polluted Sea Water}

Nitrite \& $\rightarrow$ As per standards desirable limit for nitrate Nitrate and nitrite is 0.1 to $20 \mathrm{mg} / \mathrm{l}$ in the east coast region. In all the study areas nitrate and nitrite values vary from 20 to $45 \mathrm{mg} / \mathrm{l}$ which is unfit level. Contamination affect nitrate and nitrite, it causes methemoglobinemia or blue baby diseases for human health.

Phosphate $\rightarrow$ As per standards desirable limit for phosphate is $0.03 \mathrm{mg} / \mathrm{l}$ in east coast region In all the study areas phosphate values vary from 0.5 to $1 \mathrm{mg} / \mathrm{l}$ which is unfit level. Contamination affect phosphate, it causes kidney diseases for human health.

Residual $\rightarrow$ As per standards desirable limit for residual chlorine chlorine is $0.5 \mathrm{mg} / \mathrm{l}$ in the east coast region. In all the study areas residual chlorine values vary from 2 to $3 \mathrm{mg} / \mathrm{l}$ which is unfit level. Contamination affect residual chlorine, it causes a risk of respiratory problems and asthma for human health.

Total $\rightarrow$ As per standards desirable limit for total dissolved dissolved solids is 500 to $2000 \mathrm{mg} / \mathrm{l}$ in the solids east coast region. In all the study areas total dissolved solids values vary from 3250 to $4500 \mathrm{mg} / \mathrm{l}$ which is unfit level. Contamination affect TSS, it causes harm to aquatic species more than humans.

\section{CONCLUSION}

Among the group of 12 parameters, the water samples are collecting in five places in the east coastal region. Naripaiyur is the best water sample when comparing to other places. In 12 parameters, 7 parameters like alkalinity, hardness, chloride, fluoride, nitrate, residual chlorine and iron are within permissible limits. Sethukarai and Kilakarai is the poor water sample when comparing to other places. In 12 parameters, 6 parameters like hardness, chloride, fluoride, phosphate, residual chlorine and nitrate are unfit levels. This can be reduced by providing water treatment plant and desalination plants provide nearby the study area to reduce desired contaminants and pollution levels.

\section{ACKNOWLEDGMENT}

The authors wish to acknowledge, Dr.J.Abbas Mohaideen, Principal and Dr.D.Alagia Meenal, Head, Department of Civil Engineering, Mohamed Sathak Engineering College, Kilakarai, Tamilnadu, India for support and guide to prepare this research article successfully.

\section{REFERENCES}

1. S. H. Jenkins, "Standard Methods for the Examination of Water and Wastewater," Water Research, vol. 16, no. 10, pp. 1495-1496, Jan. 1982.

2. Tayeb, M. R. Chellali, A. Hamou, and S. Debbah, "Impact of urban and industrial effluents on the coastal marine environment in Oran, Algeria," Marine Pollution Bulletin, vol. 98, no. 1-2, pp. 281-288, Sep. 2015.

3. Y. Wan, Y. Qian, K. W. Migliaccio, Y. Li, and C. Conrad, "Linking Spatial Variations in Water Quality with Water and Land Management using Multivariate Techniques," Journal of Environmental Quality, vol. 43, no. 2, pp. 599-610, Mar. 2014.
4. Anon, Standard Operating Procedure. SpringerReference Available at: http://dx.doi.org/10.1007/ springerreference_36857.

5. "Produced Wastewater Treatment Technology," Hydraulic Fracturing Wastewater, pp. 83-100, May 2017.

6. Muhammetoglu, O. B. Yalcin, and T. Ozcan, "Prediction of wastewater dilution and indicator bacteria concentrations for marine outfall systems," Marine Environmental Research, vol. 78, pp. 53-63, Jul. 2012.

7. NEERI "Determination of Existing Water Quality Status along West Coast, Beaches and Seafronts of Mumbai", MCGM, 1998.

8. NEERI "Determination of Post-commissioning Water Quality Status of West Coast beaches and seafronts around Worli Outfall" MCGM, 2000.

9. Purnama, "Modeling Dispersion of Brine Discharges from Multiple Desalination Outfalls," Springer Water, pp. 335-349, 2017.

10. "Hybrid-Design Outfalls," Marine Outfall Construction, pp 201-220, May 2009.

11. Oza and L. Muralidharan, "Assessment on Accumulation of Heavy Metals and its Effect on Liver Tissues of Harpodon Nehereus from Mumbai Coast of Maharashtra, India," International Journal of Trend in Scientific Research and Development, vol. Volume-3, no. Issue-2, pp. 214-218, Feb. 2019.

12. H. B. Jayasiri, C. S. Purushothaman, and A. Vennila, "Quantitative analysis of plastic debris on recreational beaches in Mumbai, India," Marine Pollution Bulletin, vol. 77, no. 1-2, pp. 107-112, Dec. 2013.

13. D. Chapolikar and M. B. Ubale, "A correlation study on physicochemical characteristics of groundwater in Thane-Belapur Industrial area, Mumbai," Current World Environment, vol. 5, no. 1, pp. 67-71, Jun. 2010.

14. S. R. Kamble and R. Vijay, "Assessment of water quality using cluster analysis in coastal region of Mumbai, India," Environmenta Monitoring and Assessment, vol. 178, no. 1-4, pp. 321-332, Sep. 2010

15. R. Vijay, P. J. Khobragade, and R. A. Sohony, "Water quality simulation of sewage impacts on the west coast of Mumbai, India," Water Science and Technology, vol. 62, no. 2, pp. 279-287, Jul. 2010.

16. The Gazette of India, The Environmental (Protection) Rules, 1986.

17. The Expert Committee, "Manual on Sewerage \& Sewage Treatment" (Second Edition), CPHEEO, Ministry of Urban Development, Government of India, December, NewDelhi, 1993

18. Zingde, M.D., Govindan, K., "Health status of Coastal waters of Mumbai and regions around. In: Sharma, V.K. (Ed.), Environmental Problems of Coastal Areas in India. Bookwell Publication, New Delhi, India, 119-132, 2000.

\section{AUTHORS PROFILE}

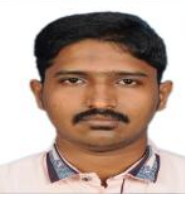

Mr S Abdul Gafoor, is working as an Assistant Professor in the Department of Civil Engineering, Mohamed Sathak Engineering College, kilakarai (First Self Financing College in Tamil Nadu). He Graduated in Civil Engineering from Mohamed Sathak Engineering college Kilakarai in the year 2015 and obtained his Master Degree in Environmental Engineering from the Algappa Chettiar Government college of Engineering and Technology, karaikudi in the year 2017. His area of interest include, Electrochemical treatment of water and waste water, synthesis of novel sustainable material for the pollution mitigation.

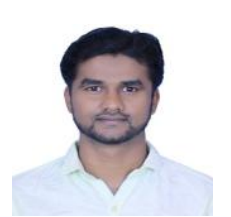

Mr.R. NasarAli, is working as a Lecturer in the Department of civil Engineering, College of Engineering And Technology, Samara University, Ethiopia. He is a member of ISTE and IAENG. He graduated in civil Engineering from Mohamed Sathak AJ College of Engineering ,Chennai, in the year 2011 and Obtained His Masters Degreein Soil mechanics and Foundation Engineering from Raja College of Engineering And Technology , Madurai in the year 2013.He joined as an Assistant professor at Mohamed sathak Engineering College, kilakarai in the year 2013. He has 3 international journal publications in the research areas of Soil Stabilization and Environmental Engineering.

Published By:

Blue Eyes Intelligence Engineering

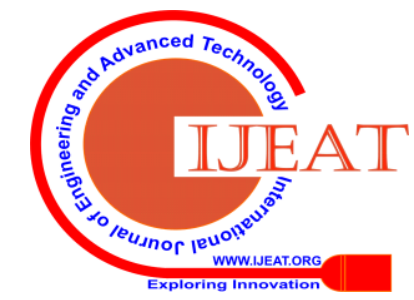


He has over 5 publication papers in international / National conferences on Geotechnical Engineering. His area of interest includes Ground improvement, Soil Structure interaction and Solid waste management.

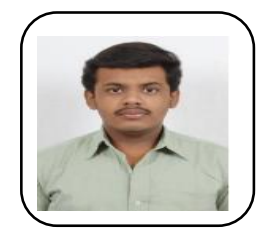

Mr.M. Shahul Hameed. Full time research scholar in Department of Civil and Environmental Engineering at NITTR, Chennai. He is life member of ISTE, IREA and IAE. He received merit fellowship from ministry of minority affairs for PG studies at Anna University and He is receiving research fellowship from ministry of HRD at NITTTR, Chennai. Engineering College. He has published 7 research activities in international journals and has applied 1 patents. His area of interest includes water pollution, wastewater treatment, and water analyzing and modeling and water management.

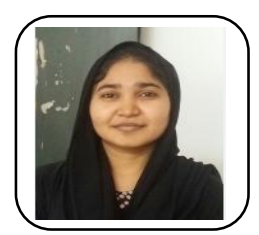

Ms. S.Sabeena Begum, is working as an Assistant Professor in the Department of Physics at the Mohamed Sathak Engineering College, Kilakarai. She is a member of ISTE. She completed M.Sc., M.Phil., B.Ed in physics. She has 2 national journal publications in the research areas of nano particles used in physics and other field. In this research, she helped to author in writing and preparation of manuscript and characterization the materials and methods.

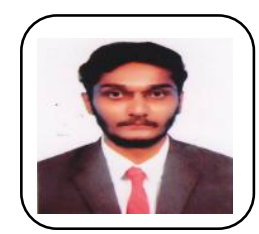

Mr. D. Zunaithur Rahman is working as an Assistant Professor in the Department of Civil Engineering at the Mohamed Sathak Engineering College, Kilakarai. He is a member of IEI, ISTE. He had bachelor degree in Civil Engineering from Noorul Islam College of Engineering, Kanyakumari, in the year 2010 and obtained his master degree in Structural Engineering from MAM College of Engineering and Technology, Trichy, in the year 2014. He has pursing his Ph.D in Anna University, Chennai from 2017. He has in total 4 international journal publications in the research areas of waste management in construction industry. His area of interest includes Sustainable materials and management, Water pollution.

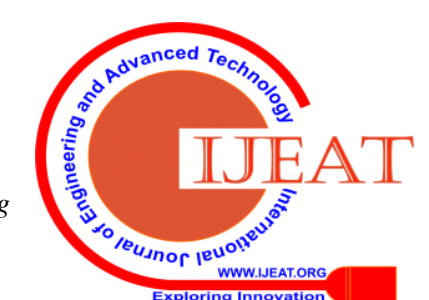

